Article

\title{
Evaluation of the Physicochemical Properties, Pharmacokinetics, and In Vitro Anticancer Effects of Docetaxel and Osthol Encapsulated in Methoxy Poly(ethylene glycol)-b-Poly(caprolactone) Polymeric Micelles
}

\author{
Min Jeong Jo ${ }^{1}$, Yu Jin Lee ${ }^{1}$, Chun-Woong Park ${ }^{1}$, Youn Bok Chung ${ }^{1}$, Jin-Seok Kim ${ }^{2}$, Mi Kyeong Lee ${ }^{1}$ \\ and Dae Hwan Shin $1, *$ \\ 1 College of Pharmacy, Chungbuk National University, Osongsaengmyeong 1-ro, Osong-eup, Heungdeok-gu, \\ Cheongju 28160, Korea; jmj950912@gmail.com (M.J.J.); 5yujinli15@gmail.com (Y.J.L.); \\ cwpark@chungbuk.ac.kr (C.-W.P.); chungyb@chungbuk.ac.kr (Y.B.C.); mklee@chungbuk.ac.kr (M.K.L.) \\ 2 Drug Information Research Institute (DIRI), College of Pharmacy, Sookmyung Women's University, \\ Cheongpa-ro 47-gil 100, Yongsan-gu, Seoul 04310, Korea; jsk9574@sookmyung.ac.kr \\ * Correspondence: dshin@chungbuk.ac.kr; Tel.: +82-43-261-2820
}

check for updates

Citation: Jo, M.J.; Lee, Y.J.; Park, C.-W.; Chung, Y.B.; Kim, J.-S.; Lee, M.K.; Shin, D.H. Evaluation of the Physicochemical Properties, Pharmacokinetics, and In Vitro

Anticancer Effects of Docetaxel and Osthol Encapsulated in Methoxy Poly(ethylene

glycol)-b-Poly(caprolactone) Polymeric Micelles. Int. J. Mol. Sci. 2021, 22, 231. https://doi.org/ 10.3390/ijms22010231

Received: 28 November 2020 Accepted: 23 December 2020 Published: 28 December 2020

Publisher's Note: MDPI stays neutral with regard to jurisdictional clai$\mathrm{ms}$ in published maps and institutional affiliations.

Copyright: (C) 2020 by the authors. Licensee MDPI, Basel, Switzerland. This article is an open access article distributed under the terms and conditions of the Creative Commons Attribution (CC BY) license (https:// creativecommons.org/licenses/by/ $4.0 /)$.

\begin{abstract}
Docetaxel (DTX), a taxane-based anticancer drug, and osthol (OTH), a coumarin-derivative compound, have shown anticancer effects against different types of cancers through various mechanisms. However, these drugs have low solubility in water and low oral bioavailability, and thus their clinical application is difficult. To overcome these problems, we encapsulated DTX and OTH in methoxy poly(ethylene glycol)- $b$-poly(caprolactone) (mPEG- $b$-PCL) and conducted studies in vitro and in vivo. We selected a 1:4 ratio as the optimal ratio of DTX and OTH, through combination index analysis in A549 cancer cells, and prepared micelles to evaluate the encapsulation efficiency, drug loading, particle size, and zeta potential. The in vitro drug-release profile showed that DTX/OTH-loaded mPEG- $b$-PCL micelles could slowly release DTX and OTH. In the clonogenic assay, DTX/OTHloaded mPEG- $b$-PCL micelles showed 3.7 times higher inhibitory effect than the DTX/OTH solution. Pharmacokinetic studies demonstrated that micelles in combination with DTX and OTH exhibited increased area under curve and decreased clearance values, as compared with single micelles.
\end{abstract}

Keywords: docetaxel; osthol; mPEG- $b$-PCL polymeric micelles; combination therapy; pharmacokinetics

\section{Introduction}

Lung cancer is one of the leading causes of cancer-related deaths worldwide [1-3]. There are two types of lung cancer, non-small-cell lung cancer and small-cell lung cancer, with the former accounting for about $80-85 \%$ of lung cancer cases $[4,5]$. Several therapies, such as chemotherapy and molecular targeted therapy, have been developed for anticancer treatment [6-8]. The commonly used chemotherapeutic drugs include taxanebased drugs, such as paclitaxel and docetaxel, as well as doxorubicin and camptothecin [9]. However, these therapies are often associated with systemic toxicity, and low drug concentrations at the tumor site can lead to multiple drug resistance [10]. In addition, high-dose medications are required to kill the tumor, which can cause serious side effects in patients [11]. Therefore, there is a need to search for new chemotherapy and drug delivery systems with improved efficacy against lung cancer.

Docetaxel (DTX) is a taxane-based drug used to treat several types of solid tumors, such as breast, head and neck, stomach, prostate, and non-small-cell lung cancer [12,13]. DTX induces cell death by inhibiting microtubule degradation and preventing microtubule aggregation $[14,15]$. It is also known to induce phosphorylation of the tumor protein bcl-2, which blocks cell death [16]. However, the anticancer effect is often reduced due to 
drug resistance of DTX. Furthermore, its solubility in water is low, which limits its clinical application [17-19].

Osthol $(\mathrm{OTH})$, a derivative of coumarin, is a natural ingredient found in a variety of plants, including Cnidium monnieri, Angelica archangelica, and Angelica pubescens [20]. Several studies have shown that OTH has antioxidant [21], anti-inflammatory [22], antiosteoporosis [23], and anti-allergic effects [24] and exhibits various biological and pharmacological activities. In addition, OTH exhibits antitumor effects by inhibiting tumor cell growth and inducing apoptosis. Jiang et al. demonstrated that OTH is a selective antitumor agent against ovarian cancer and exerts its effects by inhibiting cell proliferation, cell migration, and cell invasion, as well as by inducing apoptosis and G2/M arrest [25]. Wang et al. demonstrated that, in osteosarcoma cells, OTH inhibits induced cell-cycle arrest and migration and invasion by modulating the PTEN/Akt pathway, to alter downstream molecular expression and activity [26]. Xu et al. showed that OTH inhibits proliferation and induces apoptosis in A549 lung cancer cells through an IAP family protein, and they demonstrated that OTH enhances the antitumor effect of embelin, resulting in a synergistic effect of the two drugs [27]. Yang et al. demonstrated that OTH has antitumor activity against gastric and breast cancer cells, which is due to cell cycle arrest in the G2/M phase and apoptosis. In addition, in this study, the combination of trastuzumab and OTH was shown to be much more potent in inhibiting gastric cancer cells than either drugs alone [28]. Thus, the combination of OTH and other conventional anticancer drugs was shown to have a better effect against cancer cells than single chemotherapeutic agent. Several papers have reported that the combination of DTX and a drug with a mechanism similar to OTH used as an inhibitor of Akt exhibits a synergistic effect. Sánchez et al. demonstrated that the combination of DTX and capsaicin induces potent AMPK activation and Akt/mTOR axe inhibition in PC3 prostate tumors [29]. Singh et al. showed that the combination of DTX and thymoquinone inhibited the PI3K/Akt pathway, which induces the death of prostate cancer cells [30]. Accordingly, we predicted that the combination of DTX and OTH used as an Akt inhibitor would effectively inhibit cancer cells and exhibit a synergistic effect. However, similar to DTX, OTH is insoluble in water, and hence it has limited bioavailability [31].

Solvents such as polysorbate 80 (Tween $\left.80^{\circledR}\right)$, Cremophor EL ${ }^{\circledR}$, ethanol $(\mathrm{EtOH})$, and dimethylacetamide (DMA) are used to solubilize poorly soluble drugs in intravenous formulations. Taxotere ${ }^{\circledR}$, a formulation in which docetaxel is solubilized by using a mixture of Tween $80^{\circledR}$ and $13 \% \mathrm{EtOH}$ as a solvent, exhibited side effects, such as acute hypersensitivity reactions and peripheral neuropathy, due to the toxicity of the solvent [32]. Tween $80^{\circledR}$ also exhibits side effects, such as nonallergic anaphylaxis and rash, and has been associated with kidney and liver toxicity [33]. To replace these toxic solubilizing agents, in this study, we used micelles for the combination of DTX and OTH, using the mPEG- $b$-PCL polymer. Polymeric micelles are biocompatible, biodegradable, non-toxic, and exhibit improvement in blood flow at the treatment site, allowing for better accumulation of the drug at the tumor tissues, and thereby overcoming the effects of multiple-drug resistance [34,35]. Methoxy poly(ethylene glycol)- $b$-poly(caprolactone) (mPEG-b-PCL) is a self-assembled diblock copolymer with a hydrophilic shell (PEG) and a hydrophobic core (PCL). This polymer is characterized as being non-toxic, and its degradation products can be easily excreted and do not accumulate in vivo [36]. In addition, many studies have shown that mPEG- $b$-PCL increases the solubility of the drug, allows controlled and sustained release of the drug, and helps in maintaining better bioactivity of the drug $[37,38]$. Cho et al. demonstrated that mPEG- $b$-PCL micelles were effective in peritoneal tumors by enabling IP combination drug delivery of paclitaxel, cyclopamine, and gossypol and simultaneous sustained release of the three drugs in vitro [39].

In this study, we investigated the synergistic effect of DTX and OTH encapsulated in micelles, using mPEG- $b$-PCL. The physicochemical properties, in vitro release, in vitro cytotoxicity, and pharmacokinetic profile of the micelles were evaluated. We believe that the 
findings from this study will be of great help in facilitating clinical research and application of the combination of DTX and OTH for the treatment of lung cancer.

\section{Results}

\subsection{Evaluation of Synergistic Effects of DTX and OTH}

The potential synergistic effects of DTX and OTH were determined in A549 cells by measuring the $50 \%$ inhibition concentration $\left(\mathrm{IC}_{50}\right.$ ) values of DTX and OTH at different ratios and analyzing the combination index $(\mathrm{CI})$ values. Table 1 shows the $\mathrm{IC}_{50}$ values of DTX and OTH at each ratio, indicating that the cell proliferation inhibitory effect varied depending on the combination ratio. In addition, CI values were calculated at the ratios 11:1, 4:1, 2:1, 1:1, 1:2, 1:4, and 1:11, to determine the optimal ratio of DTX and OTH. Based on the results of the $\mathrm{CI}$ analysis, values of 1.85 and 2.97 were obtained at the ratio of 11:1 and 4:1, respectively, and these values indicated antagonism because the $\mathrm{CI}$ was greater than 1 . In contrast, when the ratio was 2:1, 1:1, 1:2, 1:4, and 1:11, the CI was less than 1, indicating synergism. Therefore, the ratio showing synergism was selected as the optimal ratio and used for the subsequent preparation of drug-loaded mPEG- $b$-PCL micelles.

Table 1. CI values of various ratios of docetaxel (DTX) and osthol (OTH).

\begin{tabular}{cccc}
\hline $\begin{array}{c}\text { DTX:OTH } \\
\text { (Molar Ratio) }\end{array}$ & DTX & IC $_{\mathbf{5 0}}(\mathbf{n M})$ & OTH \\
\hline $11: 1$ & $1214 \pm 705$ & $110 \pm 64.1$ & CI Value \\
$4: 1$ & $1947 \pm 550$ & $487 \pm 137$ & 1.85 \\
$2: 1$ & $131 \pm 60.9$ & $65.5 \pm 30.5$ & 0.20 \\
$1: 1$ & $404 \pm 206$ & $404 \pm 206$ & 0.62 \\
$1: 2$ & $343 \pm 278$ & $686 \pm 557$ & 0.53 \\
$1: 4$ & $244 \pm 101$ & $975 \pm 402$ & 0.38 \\
$1: 11$ & $68.8 \pm 23.1$ & $757 \pm 232$ & 0.11 \\
\hline
\end{tabular}

\subsection{Preparation and Characterization of DTX/OTH-Loaded mPEG-b-PCL Micelles}

Table 2 shows the results related to the encapsulation efficiency (EE, \%), drug loading (DL, \%), particle diameter, poly-dispersity index (PDI), and zeta potential of mPEG- $b$-PCL micelles loaded with DTX and OTH. It was observed that at a ratio of 2:1, the EE (\%) value of OTH was $82.2-109 \%$, which was higher than other ratios, but the EE (\%) value of DTX was $54.0-67.4 \%$, which was significantly lower than other ratios. For the remaining ratios $(1: 2,1: 4,1: 11)$, DTX showed an EE (\%) value within the range of $69.1-76.2 \%$, and OTH showed a similar overall pattern, with an EE (\%) value of $74.5-82.3 \%$. Furthermore, the overall drug-loading value decreased as the amount of polymer increased. Therefore, we selected the 1:4 ratio, using $50 \mathrm{mg}$ of the polymer as the optimal ratio when considering various factors, and the formulation that doubled the amount of the drug was selected as the final formulation and used in further in vitro and in vivo studies. In addition, transmission electron microscopy (TEM) images showed that mPEG- $b$-PCL micelles equipped with a 1:4 ratio of DTX/OTH indicated a uniform spherical shape (Figure 1A), and the size distribution graph showed that the size of single and combined micelles was less than $100 \mathrm{~nm}$ (Figure 1B). 
Table 2. Characteristics of docetaxel (DTX) and osthol (OTH)-loaded mPEG- $b$-PCL micelles $(n=3$, mean \pm SD).

\begin{tabular}{|c|c|c|c|c|c|c|c|c|c|c|}
\hline Formulation & $\begin{array}{c}\text { Polymer } \\
\text { Amount Used } \\
(\mathrm{mg})\end{array}$ & $\begin{array}{l}\text { DTX Amount } \\
\text { Used (mg) }\end{array}$ & $\begin{array}{l}\text { OTH Amount } \\
\text { Used (mg) }\end{array}$ & $\begin{array}{l}\text { DTX Encapsu- } \\
\text { lation } \\
\text { Efficiency } \\
\text { (EE \%) }\end{array}$ & $\begin{array}{l}\text { OTH Encap- } \\
\text { sulation } \\
\text { Efficiency } \\
\text { (EE \%) }\end{array}$ & $\begin{array}{c}\text { DTX Drug } \\
\text { Loading (DL } \\
\%)\end{array}$ & $\begin{array}{c}\text { OTH Drug } \\
\text { Loading (DL } \\
\%)\end{array}$ & $\begin{array}{l}\text { Particle Size } \\
\text { (nm) }\end{array}$ & $\begin{array}{c}\text { Poly- } \\
\text { Dispersity } \\
\text { Index (PDI) }\end{array}$ & $\begin{array}{c}\text { Zeta Potential } \\
(\mathrm{mV})\end{array}$ \\
\hline \multirow{2}{*}{$\begin{array}{c}\text { DTX:OTH } \\
1: 2\end{array}$} & 100 & 4 & 2.4 & $76.2 \pm 7.27$ & $82.3 \pm 10.4$ & $2.93 \pm 0.28$ & $1.93 \pm 0.24$ & $30.9 \pm 0.99$ & $0.16 \pm 4.00$ & $2.17 \pm 1.05$ \\
\hline & 150 & 4 & 2.4 & $69.6 \pm 5.72$ & $77.3 \pm 11.8$ & $1.81 \pm 0.15$ & $1.22 \pm 0.19$ & $30.1 \pm 1.06$ & $0.08 \pm 2.31$ & $2.40 \pm 1.21$ \\
\hline \multirow{3}{*}{$\begin{array}{c}\text { DTX:OTH } \\
2: 1\end{array}$} & 50 & 6.62 & 1.0 & $54.0 \pm 18.1$ & $109 \pm 4.16$ & $6.31 \pm 2.12$ & $2.14 \pm 0.08$ & $31.3 \pm 1.52$ & $0.12 \pm 7.75$ & $-1.03 \pm 2.12$ \\
\hline & 100 & 6.62 & 1.0 & $65.4 \pm 5.31$ & $82.2 \pm 11.7$ & $4.06 \pm 0.33$ & $0.81 \pm 0.12$ & $31.4 \pm 2.22$ & $0.12 \pm 7.54$ & $1.73 \pm 0.76$ \\
\hline & 150 & 6.62 & 1.0 & $67.4 \pm 0.79$ & $95.8 \pm 32.6$ & $2.85 \pm 0.03$ & $0.63 \pm 0.22$ & $31.1 \pm 0.97$ & $0.12 \pm 4.04$ & $6.07 \pm 2.37$ \\
\hline \multirow{5}{*}{$\begin{array}{c}\text { DTX:OTH } \\
1: 4\end{array}$} & 50 & 3 & 3.6 & $72.2 \pm 10.8$ & $77.2 \pm 11.8$ & $4.09 \pm 0.61$ & $5.19 \pm 0.80$ & $31.4 \pm 0.20$ & $0.08 \pm 0.38$ & $0.53 \pm 1.46$ \\
\hline & 100 & 3 & 3.6 & $70.5 \pm 5.01$ & $78.1 \pm 5.93$ & $2.05 \pm 0.15$ & $2.72 \pm 0.21$ & $31.6 \pm 0.97$ & $0.10 \pm 1.14$ & $1.37 \pm 2.80$ \\
\hline & 150 & 3 & 3.6 & $74.2 \pm 8.55$ & $80.6 \pm 1.95$ & $1.45 \pm 0.17$ & $1.89 \pm 0.05$ & $31.5 \pm 1.29$ & $0.13 \pm 0.82$ & $4.03 \pm 2.32$ \\
\hline & 50 & 6 & 7.2 & $72.2 \pm 4.53$ & $78.6 \pm 2.38$ & $7.74 \pm 0.49$ & $9.90 \pm 0.30$ & $33.3 \pm 0.28$ & $0.09 \pm 0.67$ & $-0.60 \pm 0.78$ \\
\hline & 150 & 6 & 7.2 & $69.1 \pm 4.27$ & $77.7 \pm 3.47$ & $2.66 \pm 0.16$ & $3.56 \pm 0.16$ & $33.5 \pm 2.25$ & $0.17 \pm 5.55$ & $2.67 \pm 0.40$ \\
\hline \multirow{3}{*}{$\begin{array}{c}\text { DTX:OTH } \\
1: 11\end{array}$} & 50 & 2 & 6.6 & $74.1 \pm 5.25$ & $78.9 \pm 1.68$ & $2.85 \pm 0.20$ & $9.20 \pm 0.20$ & $32.6 \pm 0.53$ & $0.11 \pm 2.35$ & $-0.47 \pm 0.70$ \\
\hline & 100 & 2 & 6.6 & $70.5 \pm 3.11$ & $76.8 \pm 5.03$ & $1.38 \pm 0.06$ & $4.75 \pm 0.31$ & $32.4 \pm 0.36$ & $0.10 \pm 2.81$ & $3.47 \pm 0.96$ \\
\hline & 150 & 2 & 6.6 & $70.8 \pm 5.44$ & $74.5 \pm 5.86$ & $0.93 \pm 0.07$ & $3.14 \pm 0.25$ & $32.2 \pm 1.00$ & $0.16 \pm 3.59$ & $4.17 \pm 1.03$ \\
\hline
\end{tabular}


A

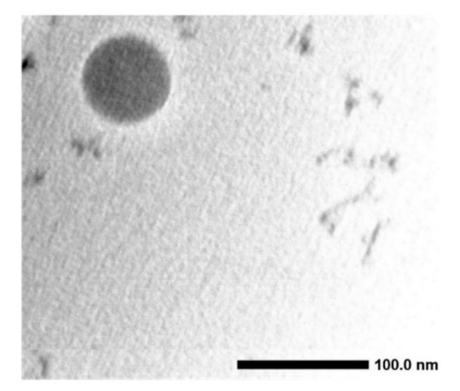

B

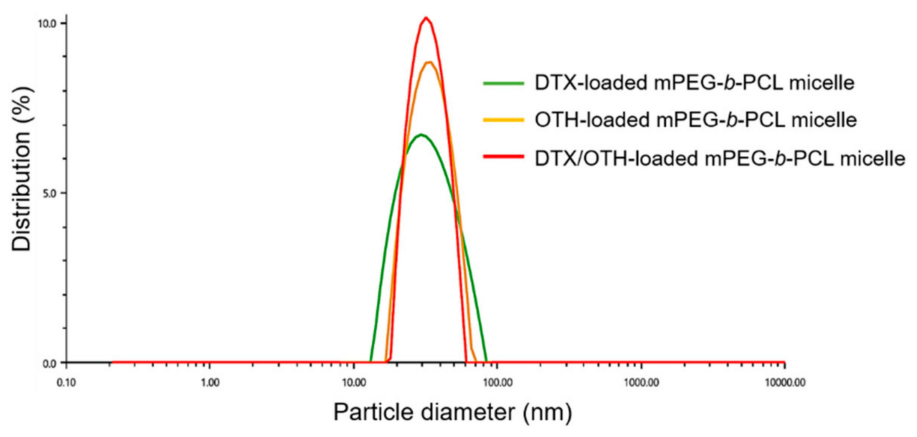

Figure 1. Transmission electron microscopy (TEM) image of docetaxel (DTX) and osthol (OTH)-loaded mPEG- $b$-PCL micelles (A). Representative size distribution analysis of DTX-loaded mPEG- $b$-PCL micelles, OTH-loaded mPEG- $b$-PCL micelles, and DTX/OTH-loaded mPEG- $b$-PCL micelles (B).

\subsection{In Vitro Drug Release Assay}

Single and combined drug-release profiles of DTX and OTH are shown in Figure 2. As shown in Figure 2A, after 6 h, the release rate of DTX was 4.4\% in DTXloaded mPEG- $b$-PCL micelles, and the release rate of DTX was $50.5 \%$ in DTX solution $(p<0.05)$. At $336 \mathrm{~h}, 96.9 \%$ of DTX was released from the DTX solution, while $70.3 \%$ of DTX was released from the DTX-loaded mPEG- $b$-PCL micelle, indicating that the release of DTX from mPEG- $b$-PCL micelles was slower than that from the solution $(p<0.05)$. Figure 2B shows that, during the first $72 \mathrm{~h}$, the DTX release rate of the DTX/OTH solution was $82.3 \%$, and that of DTX/OTH-loaded mPEG- $b$-PCL micelles was $47.4 \%$, indicating that the drug release from the micelles was slower than that from the solution $(p<0.05)$. In Figure 2C, the release rate of OTH in OTH-loaded mPEG- $b$-PCL micelles during the first $72 \mathrm{~h}$ was $73.5 \%$, and the release rate of OTH in OTH solution was $81.5 \%$. Similarly, Figure 2D shows that, during the first $72 \mathrm{~h}$, the release rate of OTH in the DTX/OTH-loaded mPEG- $b$-PCL micelles was $63.2 \%$, and the release rate of OTH in the DTX/OTH solution was $80.6 \%(p<0.05)$, which indicates that the drug release from micelles was slower than for the solution.

\subsection{Cytotoxicity of DTX/OTH-Loaded mPEG-b-PCL Micelles in A549 Cells}

Figure 3 shows the cytotoxicity results of DTX, OTH, and DTX, as well as OTH combinations with the final ratio of DTX and OTH of 1:4. The $\mathrm{IC}_{50}$ value of the DTX free drug was $657.3 \mathrm{nM}$ (Figure $3 \mathrm{~A}$ ), and the $\mathrm{IC}_{50}$ value of DTX-loaded mPEG- $b$-PCL was $1664 \mathrm{nM}$ (Figure 3B). In addition, the $\mathrm{IC}_{50}$ value of OTH free drug was 121,741 nM (Figure $3 \mathrm{C}$ ), and the $\mathrm{IC}_{50}$ value of OTH-loaded mPEG- $b$-PCL was $863,565 \mathrm{nM}$ (Figure 3D). Finally, the $\mathrm{IC}_{50}$ value of DTX/OTH free drug was $1219 \mathrm{nM}$ (Figure $3 \mathrm{E}$ ), and the $\mathrm{IC}_{50}$ value of DTX/OTH-loaded mPEG- $b$-PCL was 2852 nM (Figure 3F). 

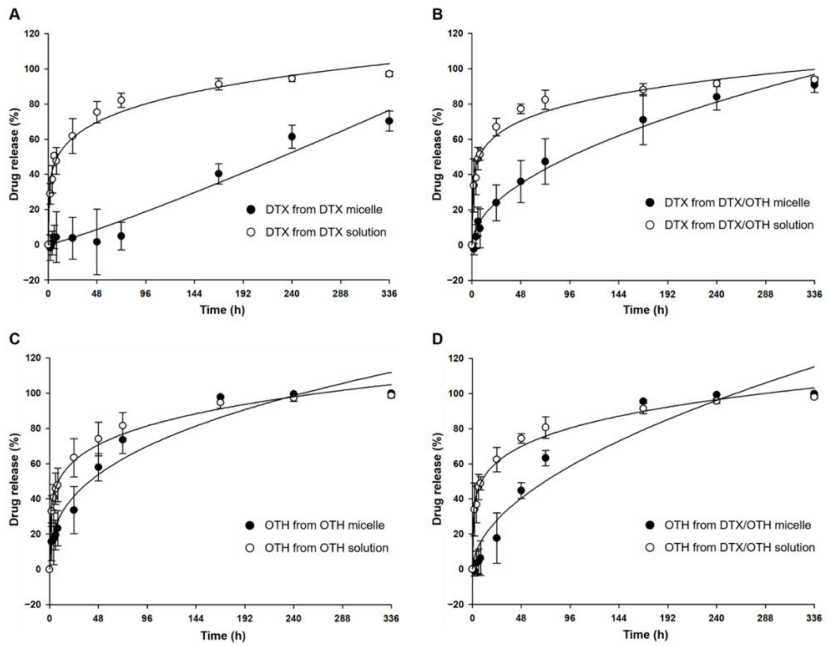

Figure 2. Single and combined drug-release profiles of docetaxel (DTX) and osthol (OTH). (A) DTX release in DTX-loaded mPEG- $b$-PCL micelles and DTX solution, (B) DTX release in DTX/OTHloaded mPEG- $b$-PCL micelles and DTX/OTH solution, (C) OTH release in OTH-loaded mPEG- $b$-PCL micelles and OTH solution, and (D) OTH release in DTX/OTH-loaded mPEG- $b$-PCL micelles and DTX/OTH solution.

A

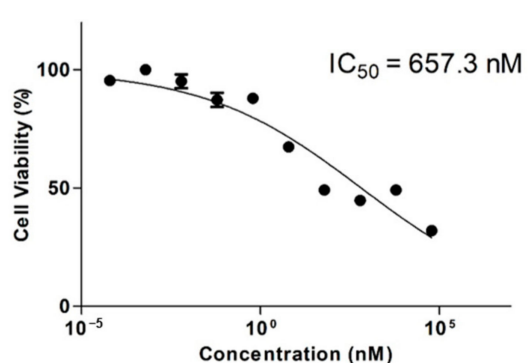

C

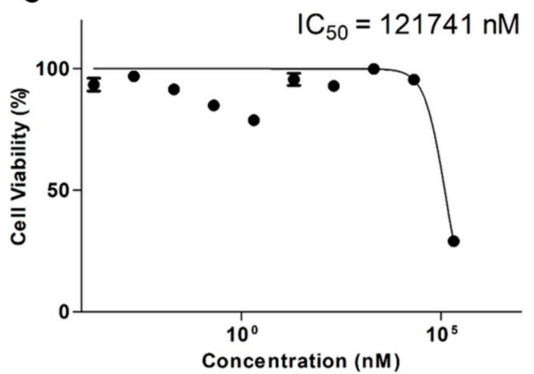

E

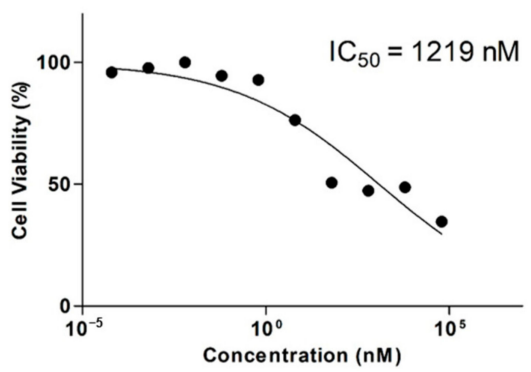

B

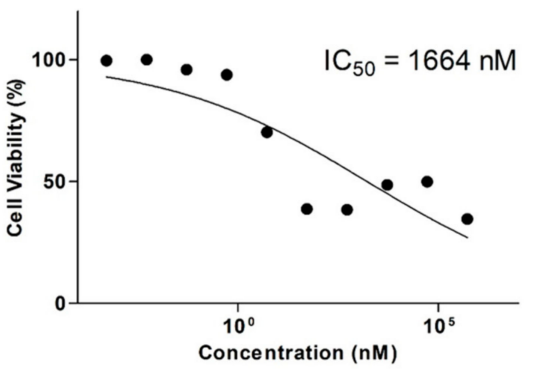

D

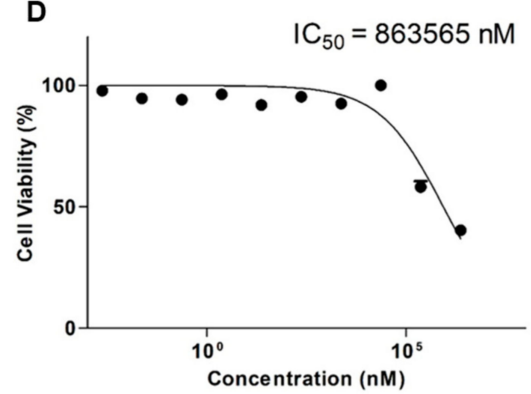

F

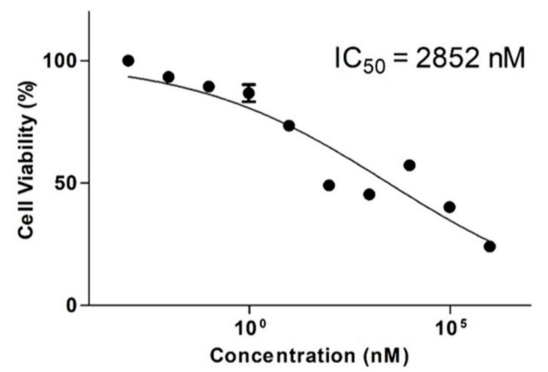

Figure 3. In vitro cytotoxicity assay results after the treatment of A549 cells with (A) docetaxel (DTX) free drug, (B) DTXloaded mPEG- $b$-PCL micelles, (C) osthol (OTH) free drug, (D) OTH-loaded mPEG- $b$-PCL micelles, (E) DTX/OTH free drug, and (F) DTX/OTH-loaded mPEG- $b$-PCL micelles. 


\subsection{Clonogenic Assay}

To assess cytotoxicity over a long period of time, a clonogenic assay was performed by calculating the $\mathrm{IC}_{50}$ values at different concentrations (Figure 4 ). When comparing the single formulation of DTX and OTH, there was little or no colony inhibitory effect, but in the combined formulation, DTX/OTH-loaded mPEG- $b$-PCL micelles inhibited colony formation that was 3.7 times higher than that of the DTX/OTH free drug.

A

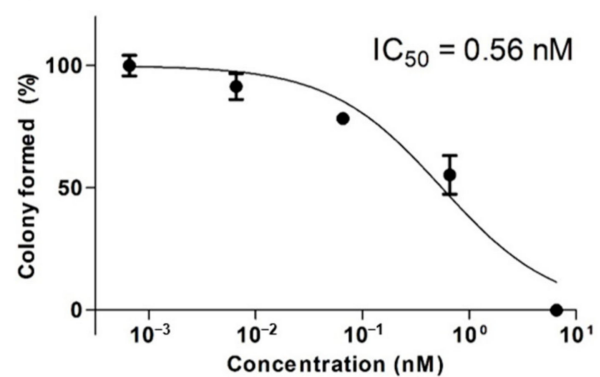

C

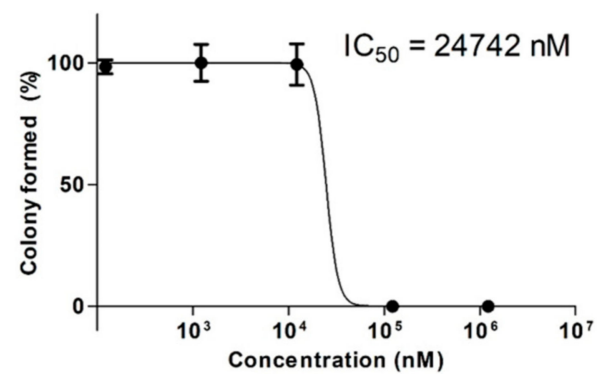

E

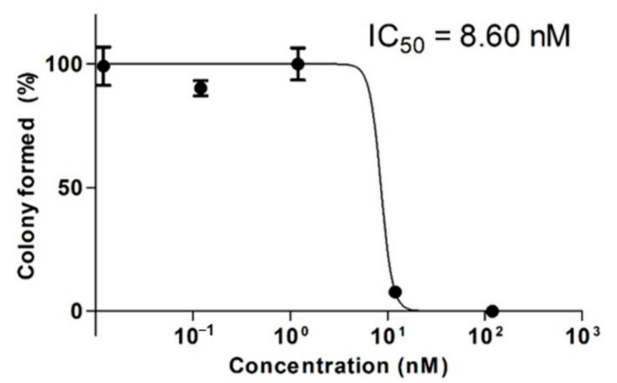

B

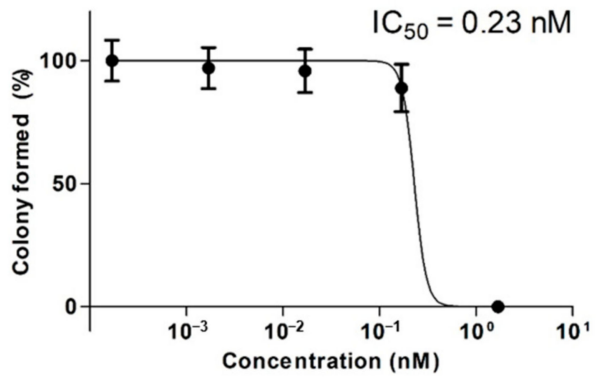

D

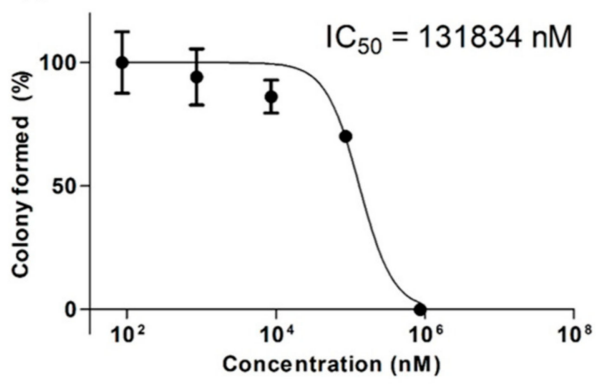

$\mathbf{F}$

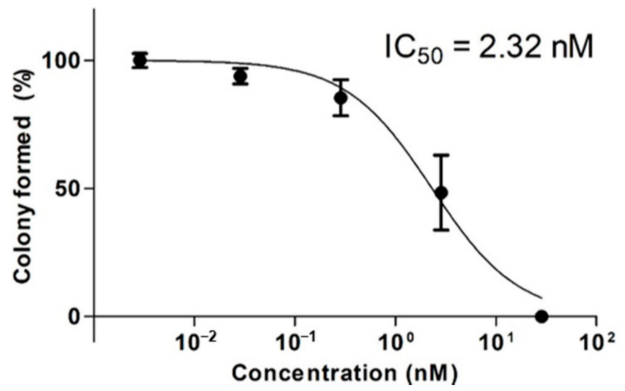

Figure 4. In vitro clonogenic assay results after the treatment of A549 cells with (A) docetaxel (DTX) free drug, (B) DTXloaded mPEG- $b$-PCL micelles, (C) osthol (OTH) free drug, (D) OTH-loaded mPEG- $b$-PCL micelles, (E) DTX/OTH free drug, and (F) DTX/OTH-loaded mPEG- $b$-PCL micelles.

\subsection{In Vivo Pharmacokinetic Study}

Plasma concentration-time profiles and pharmacokinetic parameters for single and combination formulations of DTX and OTH are shown in Figure 5 and Table 3. As shown in Figure 5A, the plasma concentration of DTX in the single formulation was detected up to $30 \mathrm{~min}$ in both micelles and the solution, and after $1 \mathrm{~h}$, the concentration was not detected below the limit of detection (LOD). Figure 5B shows that in the formulation using DTX and OTH in combination, DTX plasma concentration was detected up to $30 \mathrm{~min}$ in the solution, whereas, it was detected up to $1 \mathrm{~h}$ in micelles. In addition, DTX solution had a slightly higher area under curve (AUC) value than micelles in the single formulation, but there was no significant difference (Table 3). In contrast, in the combination formulation, the AUC value of DTX of the combined micelles was 1.3 times higher than that of the combination solution. In Figure 5C, the plasma concentration of OTH in the single formulation was 
detected up to $1 \mathrm{~h}$ in both micelles and solution, and after $2 \mathrm{~h}$, it was not detected below LOD. Figure 5D shows that in the plasma concentration of OTH in the combination formulation, both micelles and solutions were detected up to $1 \mathrm{~h}$, similar to the single formulation. The parameters of OTH showed a significant difference in the AUC value of OTH in the single formulation solution and micelles $(p<0.05)$, and the AUC value of OTH in the combined solution was slightly higher than that of the combined micelles, but there was no significant difference.
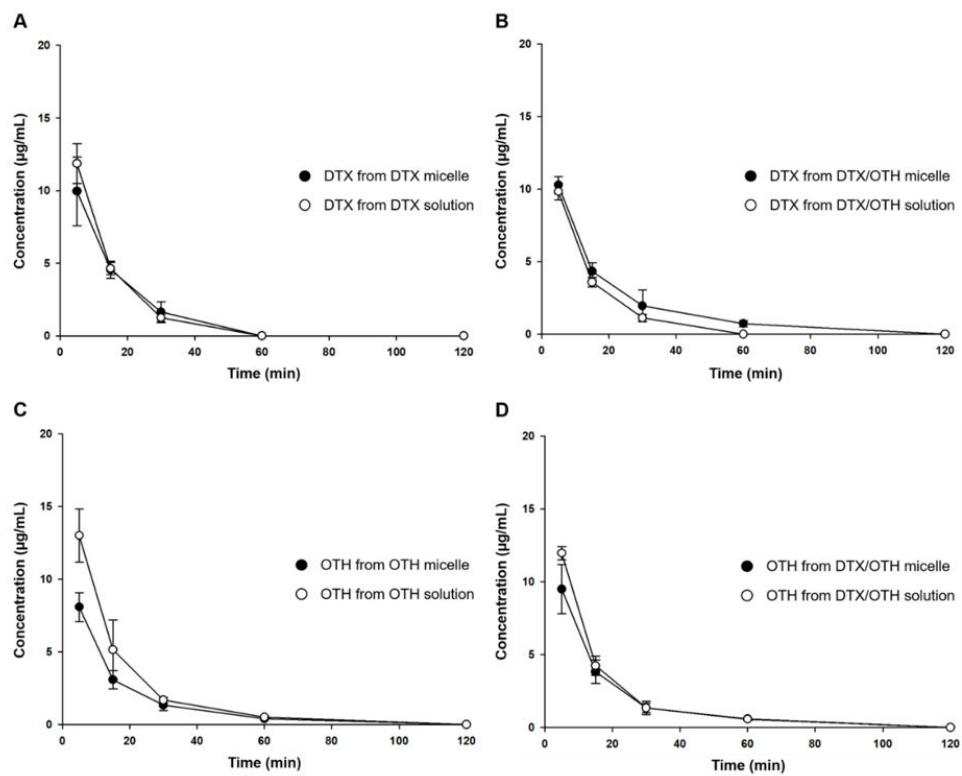

Figure 5. Plasma concentration-time profiles after intravenous injection of docetaxel (DTX) and osthol (OTH). (A) DTX profile in DTX-loaded mPEG- $b$-PCL micelles and DTX solution, (B) DTX profile in DTX/OTH-loaded mPEG- $b$-PCL micelles and DTX/OTH solution, (C) OTH profile in OTH-loaded mPEG- $b$-PCL micelles and OTH solution, and (D) OTH profile in DTX/OTH-loaded mPEG- $b$-PCL micelles and DTX/OTH solution.

Table 3. Pharmacokinetic parameters after intravenous injection of docetaxel (DTX) and osthol (OTH).

\begin{tabular}{|c|c|c|c|c|c|c|c|c|}
\hline Parameters & $\begin{array}{c}\text { DTX } \\
\text { Solution }\end{array}$ & $\begin{array}{c}\text { DTX } \\
\text { Micelle }\end{array}$ & $\begin{array}{c}\text { OTH } \\
\text { Solution }\end{array}$ & $\begin{array}{c}\text { OTH } \\
\text { Micelle }\end{array}$ & $\begin{array}{l}\text { DTX in } \\
\text { Combina- } \\
\text { tion } \\
\text { Solution }\end{array}$ & $\begin{array}{l}\text { DTX in } \\
\text { Combina- } \\
\text { tion } \\
\text { Micelle }\end{array}$ & $\begin{array}{l}\text { OTH in } \\
\text { Combina- } \\
\text { tion } \\
\text { Solution }\end{array}$ & $\begin{array}{l}\text { OTH in } \\
\text { Combina- } \\
\text { tion } \\
\text { Micelle }\end{array}$ \\
\hline $\begin{array}{c}\text { Dose } \\
\left(\mu \mathrm{g} \cdot \mathrm{kg}^{-1}\right)\end{array}$ & 10,000 & 10,000 & 12,000 & 12,000 & 10,000 & 10,000 & 12,000 & 12,000 \\
\hline $\begin{array}{c}\mathrm{AUC} \\
\left(\mathrm{min} \cdot \mu \mathrm{g} \cdot \mathrm{mL}^{-1}\right.\end{array}$ & $222 \pm 16.6$ & $205 \pm 43.3$ & $274 \pm 41.6$ & $177 \pm 23.5$ & $183 \pm 11.7$ & $244 \pm 42.4$ & $246 \pm 7.3$ & $212 \pm 24.2$ \\
\hline $\begin{array}{c}\mathrm{CL}_{\mathrm{t}} \\
\left(\mathrm{mL} \cdot \mathrm{kg}^{-1} \cdot \mathrm{min}\right.\end{array}$ & $45.2 \pm 3.44$ & $50.1 \pm 9.47$ & $44.6 \pm 7.37$ & $68.5 \pm 9.3$ & $54.8 \pm 3.65$ & $41.8 \pm 7.4$ & $48.7 \pm 1.45$ & $57.1 \pm 6.21$ \\
\hline
\end{tabular}

${ }^{a} \mathrm{AUC}$, area under the curve; ${ }^{\mathrm{c}} \mathrm{CL}_{\mathrm{t}}$, total clearance.

\subsection{Biodistribution Study}

Figure 6 shows a graph of drug distribution in major organs, at $8 \mathrm{~h}$ after intravenous injection. DTX was detected in some organs, but OTH was not detected in all organs. DTX was found to be distributed in the lungs and spleen, both in solution and micelles. Among the two organs, the DTX concentration of combined micelles was the highest in the lungs, while that in the spleen was 1.3 times lower than that in the lungs. In addition, compared to 
single micelles, higher amounts of DTX were detected in both the spleen and lung for combined micelles (no significant difference).

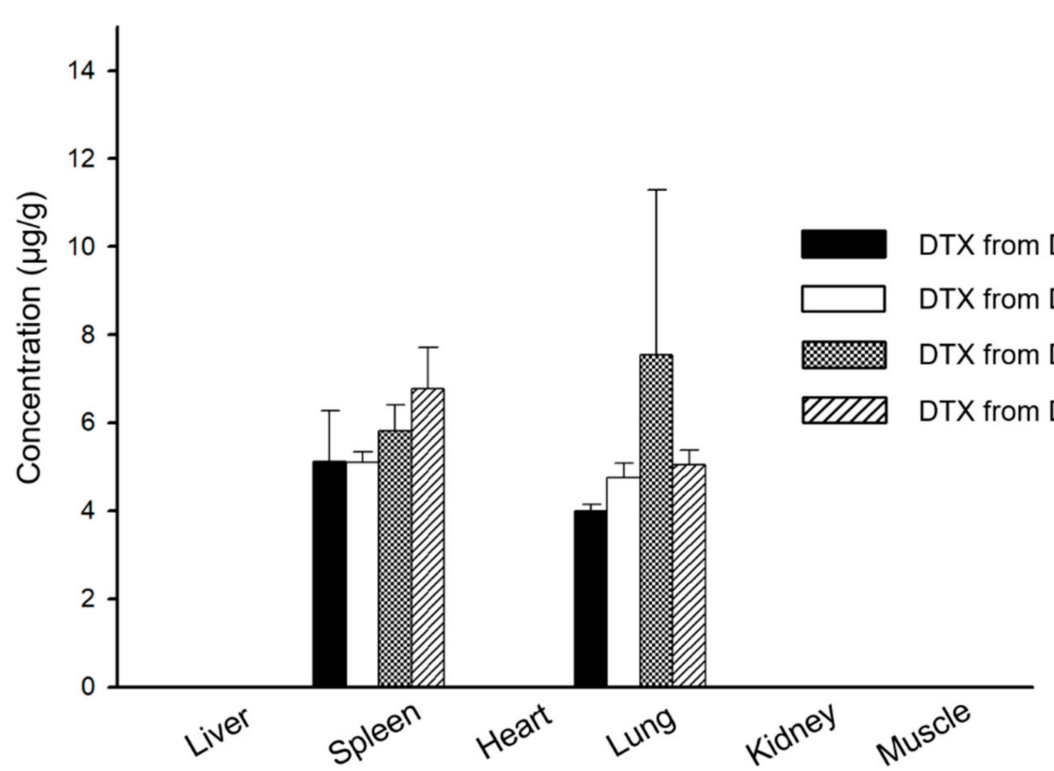

Figure 6. Biodistribution of docetaxel (DTX) in single and combined formulations, at $8 \mathrm{~h}$ after intravenous injection, in each tissue.

\section{Discussion}

DTX and OTH are widely used for the treatment of various types of cancers and have a variety of biological and pharmacological activities. However, low solubility in water and low oral bioavailability have limited their clinical application $[40,41]$. To overcome these disadvantages, we selected micelles for the solubilization of DTX and OTH and expected the synergistic effect of the two drugs. Before encapsulating the two drugs in micelles, we evaluated the CI value to find the optimal ratio at which the synergistic effect of DTX and OTH could be achieved. Among the four ratios evaluated (1:2, 2:1, 1:4, and 1:11), the ratio showing the smallest $\mathrm{CI}$ value (CI value less than 1 ) was selected and used for micelle formulation. Micelles were prepared at each ratio, and the physicochemical properties, including EE (\%), particle size, PDI, and zeta potential, were evaluated. Finally, a 1:4 ratio was chosen with an optimal formulation with low CI values of 0.38 , high EE (\%) and DL $(\%)$, appropriate particle size, and low PDI values. In addition, we hypothesized that by doubling the amount of the drug, a higher plasma concentration could be achieved in the subsequent in vivo study. Dynamic light scattering (DLS) analysis, TEM, and sizedistribution graph results showed that the size of micelles was less than $100 \mathrm{~nm}$. These results show that micelles with a particle size of less than $100 \mathrm{~nm}$ may allow very low absorption by the reticuloendothelial system (RES) and their accumulation into tumors through enhanced permeability and retention (EPR) effects [42]. Results from the in vitro release profiles of both DTX and OTH showed that drug release rate from the micelles was slower than those from the solution. These results suggest that the drug is trapped in the micelles, limiting the rapid release of the drug. It has also been shown that hydrophobic drug-encapsulated micelle carriers increase the solubility of drug and enable slower release of the drug [43]. In an in vitro cytotoxicity assay, the cytotoxic results of DTX and OTH were confirmed at $48 \mathrm{~h}$. The IC 50 values of both DTX and OTH were higher in micelle formulations than in the free drugs, which can be explained in relation to the release profile. The $48 \mathrm{~h}$ release rate of DTX in DTX/OTH solution was $77.2 \%$, whereas the release rate of DTX in DTX/OTH-loaded mPEG- $b$-PCL micelles was only $36 \%$. Similarly, the $48 \mathrm{~h}$ release rate of OTH in DTX/OTH solution was $74.4 \%$, while that of the DTX/OTH- 
loaded mPEG- $b$-PCL micelles was only $44.8 \%$. Based on these findings, it was evident that the cytotoxic effect of the drugs in the micelles was lower than the free drug due to the slow release of the drug in the micelles over $48 \mathrm{~h}$. In addition, while free drugs can enter the cell membrane by passive diffusion, micelles have a slower endocytosis process, and regulation of drug release may delay the process of cancer cell death [44]. In the clonogenic assay, the rate of colony inhibition of DTX and OTH over two weeks was confirmed. In the single formulation of DTX and OTH, the colony inhibition rate of micelles was slightly higher or lower than that of the free drug, but when used in combination, the colony inhibition rate of micelles was 3.7 times higher than that of the free drug. This indicated that the combination therapy was more effective in suppressing cancer cells than therapy with a single drug. In the in vivo pharmacokinetic study, single and combined formulations of DTX and OTH were analyzed, using plasma-time concentration graphs and pharmacokinetic parameters. The single formulation DTX solution and micelles had AUC values of 222 and $205 \mathrm{~min} \cdot \mu \mathrm{g} \cdot \mathrm{mL}^{-1}$, respectively, and the single formulation OTH solution and micelles showed AUC values of 274 and $177 \mathrm{~min} \cdot \mu \mathrm{g} \cdot \mathrm{mL}^{-1}$, respectively, indicating that the solution had a higher AUC value than micelles. This phenomenon is predicted to lower AUC, as DTX and OTH in micelles are rapidly distributed from the plasma to tissues after intravenous administration of the drug. Moreover, the reason that the solution has a higher AUC than the micelle may be due to the high plasma accumulation of the drug due to the significant interaction between the drug and the hydrophobic group of the fatty acid chain in the solution group. On the other hand, studies have shown that the inner core of micelles with weak hydrophobic interactions cannot capture the drug, which is thought to lower the AUC of the drug in the plasma [45-49]. However, a comparison of single micelles and combined micelles showed that using DTX and OTH together increased the AUC value and decreased the $C L_{t}$ value. These results indicate that the bioavailability is improved when DTX and OTH are used in combination than when using a single formulation. In the biodistribution study, DTX accumulated in the lungs and spleen, which can be seen as a result of drug absorption by the RES organ [50]. These results can be beneficial for the treatment of lung cancer, as micelles are detained in the lungs, and the drug can be continuously released [49].

\section{Materials and Methods}

\subsection{Materials and Reagents}

The mPEG- $b$-PCL (Mw 2000:2000Da) was purchased from Polyscitech. (West Lafayette, IN, USA). DTX and genistein were purchased from LC Laboratories (Woburn, MA, USA). OTH was obtained from Chungbuk National University, Cheongju, Korea and identified by Professor Mi Kyeong Lee, who specializes in natural products. Ethanol (EtOH) and acetonitrile (ACN) were purchased from Fisher Scientific Ltd. (Waltham, MA, USA). Distilled water (DW) was purchased from Tedia (Fairfield, $\mathrm{OH}, \mathrm{USA})$. Methanol (MeOH) was purchased from Honeywell Burdick and Jackson (Ulsan, Korea). Polysorbate 80 (Tween $80^{\circledR}$ ) was purchased from Sigma-Aldrich Corp. (St. Louis, MO, USA). All other chemicals were of analytical reagent grade or better.

\subsection{Methods}

\subsubsection{Cell Line and Cell Culture}

A549 cells were purchased from the American Type Culture Collection (Manassas, VA, USA). Roswell Park Memorial Institute medium (RPMI 1640), Dulbecco's modified Eagle's medium, Dulbecco's phosphate-buffered saline (DPBS), and trypsin were purchased from Corning Inc. (Corning, NY, USA). Thiazolyl blue tetrazolium bromide (MTT) was purchased from Sigma-Aldrich Corp. (St. Louis, MO, USA). The cells were cultured in RPMI medium supplemented with $1 \%(w / v)$ streptomycin/penicillin and $10 \%(v / v)$ fetal bovine serum (FBS), in a humidified $5 \% \mathrm{CO}_{2}$ atmosphere, at $37^{\circ} \mathrm{C}$. 


\subsubsection{High-Performance Liquid Chromatography (HPLC) Analysis}

The concentration of DTX and OTH in the samples was analyzed by using a Waters HPLC system (Milford, Massachusetts, USA) consisting of a 2695 separation module and a 2996 photodiode array detector. A Fortis C18 chromatography column (5 $\mu \mathrm{m}$, $4.6 \times 250 \mathrm{~mm}$ ) was used for the analysis, and the column was kept at $30^{\circ} \mathrm{C}$. DTX, OTH, and genistein (internal standard, IS) were eluted in isocratic mode; the injection volume was $10 \mu \mathrm{L}$, and the flow rate of the mobile phase consisting of ACN/water $(70: 30, v / v)$ was $1.0 \mathrm{~mL} / \mathrm{min}$. DTX, OTH, and IS were detected at the wavelengths of 230, 320, and $259 \mathrm{~nm}$, respectively. The retention times of DTX, OTH, and IS were 4.7, 8.6, and $3.5 \mathrm{~min}$, respectively. The concentration of each drug was calculated by comparing the peak areas with the calibration curve.

\subsubsection{In Vitro Cytotoxicity Assay}

The cytotoxicity of DTX/OTH-loaded mPEG-b-PCL micelles on A549 cells was evaluated by the MTT assay [51]. A549 cells were seeded in 96-well plates, at a density of 5000 cells per well and incubated at $37^{\circ} \mathrm{C}$ for $24 \mathrm{~h}$. After $24 \mathrm{~h}$, the medium was removed, and the cells were treated with free DTX, free OTH, free DTX/OTH, DTX-loaded MPEG$b$-PCL micelles, OTH-loaded mPEG- $b$-PCL micelles, or DTX/OTH-loaded mPEG- $b$-PCL micelles according to each concentration $(n=6)$. Fresh medium containing no drug was used as a control. The cells were incubated at $37^{\circ} \mathrm{C}$ for $48 \mathrm{~h}$. After $48 \mathrm{~h}$, the medium was removed, and $100 \mu \mathrm{L}$ of MTT solution $(0.5 \mathrm{mg} / \mathrm{mL})$ was added, followed by incubation for $4 \mathrm{~h}$. Then, the medium was removed, and $100 \mu \mathrm{L}$ of dimethyl sulfoxide was added, and the plate was shaken for $10 \mathrm{~min}$ at $200 \mathrm{rpm}$. Absorbance was measured at $540 \mathrm{~nm}$, using a microplate reader (Spectra Max ID3, Molecular Devices, San Jose, CA, USA). All data processing was analyzed by using GraphPad Prism 5 software (GraphPad Software, La Jolla, CA, USA).

\subsubsection{Combination Index (CI) Analysis}

$\mathrm{CI}$ analysis was performed according to Chou's method to assess drug interaction between drugs [52]. The CI values of DTX and OTH were calculated by using the following equation:

$$
\text { Combination index }(C I)=(D)_{1} /\left(D_{\mathrm{x}}\right)_{1}+(D)_{2} /\left(D_{\mathrm{x}}\right)_{2}
$$

where is $\left(D_{\mathrm{x}}\right)_{1}$ and $\left(\mathrm{D}_{\mathrm{x}}\right)_{2}$ are the inhibitory concentrations of drug 1 and drug 2, respectively. $(\mathrm{D})_{1}$ and $(\mathrm{D})_{2}$ are the inhibitory concentrations of each drug in the combination. $\mathrm{CI}>1$ indicates antagonism, $\mathrm{CI}<1$ indicates synergism, and $\mathrm{CI}=1$ indicates an additive effect.

\subsubsection{Clonogenic Assay}

A549 cells were seeded in 6-well plates, at a density of 200 cells per well, and incubated at $37^{\circ} \mathrm{C}$ for $24 \mathrm{~h}$. After confirming cell adhesion, the cells were treated with free DTX, free OTH, free DTX/OTH, DTX-loaded mPEG- $b$-PCL micelles, OTH-loaded mPEG- $b$-PCL micelles, or DTX/OTH-loaded mPEG- $b$-PCL micelles. After two weeks, the medium was removed, and $1 \mathrm{~mL}$ of crystal violet $(0.5 \% w / v)$ was added to each well. After incubation for $30 \mathrm{~min}$, the crystal violet was rinsed with clean water, and the number of colonies was measured. The colony formation percentage was calculated by using the equation below:

Colony formation $(\%$ of control $)=$ Number of colonies after treatment/Number of colonies of control (PBS) $\times 100$

\subsubsection{Preparation of DTX- and OTH-Loaded Polymeric Micelles}

DTX- and OTH-loaded mPEG- $b$-PCL micelles were prepared by using the thin-film hydration method [53]. Briefly, various ratios of DTX and OTH were mixed with mPEG$b$-PCL, dissolved in $1 \mathrm{~mL}$ of ACN, and placed in a round-bottomed flask. The DTX and OTH-polymer mixture was evaporated under vacuum, using a EYELA ${ }^{\circledR}$ rotary evaporator (Bohemia, NY, USA), in a water bath, for $10 \mathrm{~min}$, maintained at $60^{\circ} \mathrm{C}$. After a thin film 
was formed, $1 \mathrm{~mL}$ of DW was added, and the micelle solution obtained by hydration for $30 \mathrm{~min}$ was centrifuged at $16,600 \times g$ for $5 \mathrm{~min}$ (Hanil Science Inc., Gimpo, Korea). Then, the supernatant of the centrifuged micelles was obtained and filtered through a $0.2 \mu \mathrm{m}$ filter, and the physicochemical properties of the micelles were confirmed.

\subsubsection{Physicochemical Characterization of Micelles}

The particle size and zeta potential of DTX/OTH-loaded mPEG-b-PCL micelles were measured by using a dynamic light scattering (DLS) device (Litesizer 500, Anton Paar, Graz, Austria). Each sample was diluted 10 times prior to measurement. The drug content of mPEG- $b$-PCL micelles was analyzed by HPLC, under the conditions mentioned in Section 4.2.2. Then, $20 \mu \mathrm{L}$ of drug-loaded mPEG- $b$-PCL micelle solution was dissolved in $180 \mu \mathrm{L}$ of ACN. The encapsulation efficiency (EE, \%) and drug loading (DL, \%) of DTX and OTH were calculated by using the equation below [54-56]:

$$
\begin{gathered}
\mathrm{DL} \%=\text { Weight of drug in micelles } / \text { weight of feeding drug and polymer } \times 100 \\
\mathrm{EE} \%=\text { Weight of drug in micelles } / \text { weight of feeding drug } \times 100
\end{gathered}
$$

The morphology of DTX/OTH-loaded mPEG- $b$-PCL micelles was observed by using a JEM-2100 transmission electron microscope (TEM, JEOL Ltd., Tokyo, Japan). In the sample preparation procedure for TEM measurement, the diluted micelle solution was dropped on 200-mesh formvar-coated copper grids and dried in a dry oven at $60^{\circ} \mathrm{C}$ for $12 \mathrm{~h}$. The results of each sample analysis are presented as the mean \pm standard deviation of three separate experiments.

\subsubsection{In Vitro Drug Release Assay}

The in vitro release profile of DTX and OTH in the micelles was evaluated by using a dialysis method in phosphate-buffered saline (PBS, pH 7.4) [57]. Briefly, DTX solution, OTH solution, DTX/OTH solution, DTX-loaded mPEG-b-PCL, OTH-loaded mPEG- $b$-PCL micelles, and DTX/OTH-loaded mPEG- $b$-PCL micelles were placed in a dialysis membrane (MWCO $20 \mathrm{kD}$ ) of $2.0 \mathrm{~L}$ release medium, stirred at $200 \mathrm{rpm}$, at $37^{\circ} \mathrm{C}$. The solution was prepared in a ratio of $25 \%, 10 \%$, and $65 \%$ of Tween $80^{\circledR}, \mathrm{EtOH}$, and DW, respectively, using the same solvent $\left(\right.$ Taxotere ${ }^{\circledR}$ ) as the control. In both in vitro release experiments and pharmacokinetic experiments, DTX solution and micelles were used at a concentration of $4 \mathrm{mg} / \mathrm{mL}$, and OTH was used at a concentration of $5 \mathrm{mg} / \mathrm{mL}$. At each sampling time point $(0,2,4,6,8,24,48,72,168,240$, and $336 \mathrm{~h}), 20 \mu \mathrm{L}$ of each sample was withdrawn, and then each sample was diluted 10 times with ACN, and the DTX and OTH concentrations were measured by HPLC. The PBS release medium was replaced with fresh media at 8, 72, 144, 216, and 288 h. All experiments were conducted three times.

\subsubsection{Pharmacokinetic Study}

Sprague-Dawley rats (male, 7 weeks old) were obtained from Orient Bio Inc. (Seongnam, Korea) for pharmacokinetic studies. Animal experiments were approved by the Institutional Animal Care and Use Committee (IACUC) of Chungbuk National University (CBNUR-1405-20, 23 July 2020). All rats were maintained in well-ventilated cages and fed with adequate amounts of water and food. The rats were divided into six groups: DTX solution, OTH solution, DTX/OTH solution, DTX-loaded mPEG- $b$-PCL micelles, OTH-loaded mPEG- $b$-PCL micelles, and DTX/OTH-loaded mPEG- $b$-PCL micelles. The micelles were injected with a size of $30 \mathrm{~nm}$, and the solution was used with the same solvent as mentioned in Section 4.2.8. Each sample was injected intravenously, and DTX was administered at a dose of $10 \mathrm{mg} / \mathrm{kg}$ and OTH $12 \mathrm{mg} / \mathrm{kg}$. At predetermined time intervals $(5,15,30,60,120$, 240 , and $480 \mathrm{~min}$ ), $500 \mu \mathrm{L}$ of blood was collected from the retro-orbital plexus and placed in a heparin tube. Then, the samples were immediately separated by centrifugation at $16,600 \times \mathrm{g}$ for $5 \mathrm{~min}$ and stored at $-70^{\circ} \mathrm{C}$, until analysis. The pharmacokinetic parameters, including initial blood concentration $\left(\mathrm{C}_{0}\right)$, area under the concentration-time curve (AUC), 
volume of distribution $\left(\mathrm{V}_{\mathrm{d}}\right)$, and total clearance $\left(\mathrm{CL}_{\mathrm{t}}\right)$ were calculated by using Sigma Plot 10.0 (Systat Software, San Jose, CA, USA). All experiments were repeated three times.

\subsubsection{Biodistribution Study}

A biodistribution study was performed to evaluate the tissue distribution of DTX and OTH formulations after pharmacokinetic studies were performed. The rats were euthanized, using $\mathrm{CO}_{2}$ gas $8 \mathrm{~h}$ after administration. Tissue samples from the liver, spleen, heart, lungs, kidneys, and muscles were collected. Each sample was washed with saline and wiped with a paper towel and stored at $-70^{\circ} \mathrm{C}$, until analysis.

\subsubsection{Biological Sample Pretreatment for HPLC Analysis}

Plasma samples that were frozen before analysis were thawed at ambient temperature. To a $200 \mu \mathrm{L}$ of plasma sample, $400 \mu \mathrm{L}$ of $\mathrm{MeOH}$ and $50 \mu \mathrm{L}$ of IS were added, followed by centrifugation at $16,600 \times g$ for $5 \mathrm{~min}$. The supernatant was filtered through a $0.2 \mu \mathrm{m}$ cellulose filter and analyzed by HPLC [49]. Biodistribution samples were evaluated using the homogenization method [58]. Briefly, each tissue sample (liver, spleen, heart, lungs, kidneys, and muscles) was homogenized with a Teflon pestle into a glass Potter-Elvehjemtype homogenizer (Ultra Turrax T-25; IKAWorks Inc., Staufen, Germany). Then, $200 \mu \mathrm{L}$ of each tissue sample was collected, $\mathrm{MeOH}$ and IS were added and pretreated in the same manner as described above, and the concentrations of DTX and OTH were analyzed by HPLC, as mentioned in Section 4.2.2.

\subsubsection{Statistical Analysis}

All experiments were performed in triplicate, and all data values are expressed as mean \pm SD. Statistical analysis was performed by using ANOVA of GraphPad Prism v 5.0 (GraphPad Software, La Jolla, CA, USA), and values of $p<0.05$ are considered significant.

\section{Conclusions}

In conclusion, we prepared polymeric micelles for solubilization of DTX and OTH and investigated the synergistic effects of the two drugs. In vitro studies showed that DTX/OTH-loaded mPEG-b-PCL micelles were released more slowly than DTX/OTH solutions, and showed higher colony inhibition rate than DTX/OTH-free drugs. In pharmacokinetic studies, micelles in combination with DTX and OTH showed increased AUC than single micelles and had improved bioavailability. Therefore, the synergistic effect of DTX and OTH offers a promising treatment strategy for lung cancer and will be of value for future preclinical studies.

Author Contributions: Conceptualization, M.J.J. and D.H.S.; methodology, M.J.J.; software, M.J.J.; validation, M.J.J. and D.H.S.; formal analysis, M.J.J; investigation, M.J.J.; resources, M.J.J.; data curation, M.J.J.; writing—original draft preparation, M.J.J.; writing—review and editing, M.J.J., Y.J.L., and D.H.S.; visualization, M.J.J. and Y.J.L.; supervision, C.-W.P., Y.B.C., J.-S.K., and M.K.L.; project administration, M.J.J. and D.H.S. All authors have read and agreed to the published version of the manuscript.

Funding: This research was funded by the Basic Science Research Program through the National Research Foundation of Korea (NRF), funded by the Ministry of Education, grant number NRF2019R1C1C1009996.

Institutional Review Board Statement: The study was approved by the Institutional Animal Care and Use Committee (IACUC) of Chungbuk National University (CBNUR-1405-20, 23 July 2020).

Informed Consent Statement: Not applicable.

Data Availability Statement: All the data is actually available and the article contains the data.

Acknowledgments: The authors would like to thank Ik Sup Jin, Moon Sup Yoon, and Hee Ji Shin for their technical assistance.

Conflicts of Interest: The authors declare no conflict of interest. 


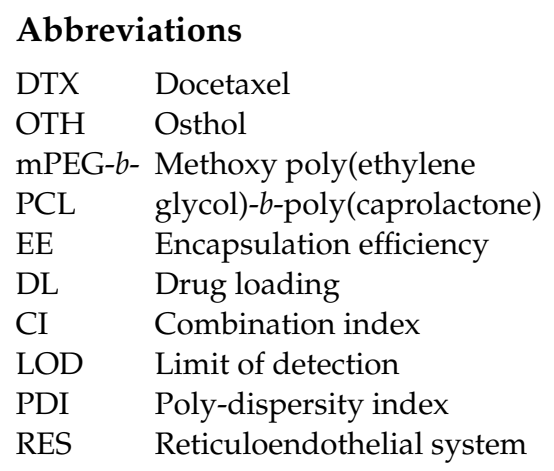

\section{References}

1. Mei, D.; Zhao, L.; Chen, B.; Zhang, X.; Wang, X.; Yu, Z.; Ni, X.; Zhang, Q. $\alpha$-Conotoxin ImI-modified polymeric micelles as potential nanocarriers for targeted docetaxel delivery to $\alpha 7$-nAChR overexpressed non-small cell lung cancer. Drug Deliv. 2018, 25, 493-503. [CrossRef] [PubMed]

2. Zhang, L.; Liu, Z.; Kong, C.; Liu, C.; Yang, K.; Chen, H.; Huang, J.; Qian, F. Improving Drug Delivery of Micellar Paclitaxel against Non-Small Cell Lung Cancer by Coloading Itraconazole as a Micelle Stabilizer and a Tumor Vascular Manipulator. Small (Weinheim an der Bergstrasse, Germany) 2018, 14, e1802112. [CrossRef] [PubMed]

3. Zhuang, B.; Du, L.; Xu, H.; Xu, X.; Wang, C.; Fan, Y.; Cong, M.; Yin, J.; Li, H.; Guan, H. Self-assembled Micelle Loading Cabazitaxel for therapy of Lung Cancer. Int. J. Pharm. 2016, 499, 146-155. [CrossRef] [PubMed]

4. Bao, Y.; Deng, Q.; Li, Y.; Zhou, S. Engineering docetaxel-loaded micelles for non-small cell lung cancer: A comparative study of microfluidic and bulk nanoparticle preparation. RSC Advances 2018, 8, 31950-31966. [CrossRef]

5. Brahmer, J.R.; Govindan, R.; Anders, R.A.; Antonia, S.J.; Sagorsky, S.; Davies, M.J.; Dubinett, S.M.; Ferris, A.; Gandhi, L.; Garon, E.B.; et al. The Society for Immunotherapy of Cancer consensus statement on immunotherapy for the treatment of non-small cell lung cancer (NSCLC). Journal for immunotherapy of cancer 2018, 6, 75. [CrossRef]

6. De Weger, V.A.; Beijnen, J.H.; Schellens, J.H. Cellular and clinical pharmacology of the taxanes docetaxel and paclitaxel-a review. Anticancer Drugs 2014, 25, 488-494. [CrossRef]

7. Hirsch, F.R.; Suda, K.; Wiens, J.; Bunn, P.A., Jr. New and emerging targeted treatments in advanced non-small-cell lung cancer. Lancet 2016, 388, 1012-1024. [CrossRef]

8. Rowinsky, E.K. The development and clinical utility of the taxane class of antimicrotubule chemotherapy agents. Annu. Rev. Med. 1997, 48, 353-374. [CrossRef]

9. Thomas, A.; Liu, S.V.; Subramaniam, D.S.; Giaccone, G. Refining the treatment of NSCLC according to histological and molecular subtypes. Nat. Rev. Clin. Oncol. 2015, 12, 511-526. [CrossRef]

10. Jinturkar, K.A.; Anish, C.; Kumar, M.K.; Bagchi, T.; Panda, A.K.; Misra, A.R. Liposomal formulations of Etoposide and Docetaxel for p53 mediated enhanced cytotoxicity in lung cancer cell lines. Biomaterials 2012, 33, 2492-2507. [CrossRef]

11. Zarogoulidis, P.; Chatzaki, E.; Porpodis, K.; Domvri, K.; Hohenforst-Schmidt, W.; Goldberg, E.P.; Karamanos, N.; Zarogoulidis, K. Inhaled chemotherapy in lung cancer: Future concept of nanomedicine. International journal of nanomedicine 2012, 7, 1551-1572. [CrossRef] [PubMed]

12. Chen, X.; Zhao, L.; Kang, Y.; He, Z.; Xiong, F.; Ling, X.; Wu, J. Significant Suppression of Non-small-cell Lung Cancer by Hydrophobic Poly(ester amide) Nanoparticles with High Docetaxel Loading. Front. Pharmacol. 2018, 9, 118. [CrossRef] [PubMed]

13. Lee, S.W.; Yun, M.H.; Jeong, S.W.; In, C.H.; Kim, J.Y.; Seo, M.H.; Pai, C.M.; Kim, S.O. Development of docetaxel-loaded intravenous formulation, Nanoxel-PM ${ }^{\mathrm{TM}}$ using polymer-based delivery system. J. Control. Release 2011, 155, 262-271. [CrossRef] [PubMed]

14. Herbst, R.S.; Khuri, F.R. Mode of action of docetaxel - a basis for combination with novel anticancer agents. Cancer Treat. Rev. 2003, 29, 407-415. [CrossRef]

15. Horwitz, S.B. Mechanism of action of taxol. Trends Pharmacol. Sci. 1992, 13, 134-136. [CrossRef]

16. Lyseng-Williamson, K.A.; Fenton, C. Docetaxel: A review of its use in metastatic breast cancer. Drugs 2005, 65, 2513-2531. [CrossRef]

17. Qi, D.; Gong, F.; Teng, X.; Ma, M.; Wen, H.; Yuan, W.; Cheng, Y.; Lu, C. Design and evaluation of mPEG-PLA micelles functionalized with drug-interactive domains as improved drug carriers for docetaxel delivery. J. Biomater. Sci. Polym. Ed. 2017, 28, 1538-1555. [CrossRef]

18. Su, C.Y.; Liu, J.J.; Ho, Y.S.; Huang, Y.Y.; Chang, V.H.; Liu, D.Z.; Chen, L.C.; Ho, H.O.; Sheu, M.T. Development and characterization of docetaxel-loaded lecithin-stabilized micellar drug delivery system (L(sb)MDDs) for improving the therapeutic efficacy and reducing systemic toxicity. Eur. J. Pharm. Biopharm. 2018, 123, 9-19. [CrossRef]

19. Galletti, E.; Magnani, M.; Renzulli, M.L.; Botta, M. Paclitaxel and docetaxel resistance: Molecular mechanisms and development of new generation taxanes. ChemMedChem 2007, 2, 920-942. [CrossRef]

20. Zhang, Z.R.; Leung, W.N.; Cheung, H.Y.; Chan, C.W. Osthole: A Review on Its Bioactivities, Pharmacological Properties, and Potential as Alternative Medicine. Evid. Based Complement. Alternat. Med. 2015, 2015, 919616. [CrossRef] 
21. Liu, W.B.; Zhou, J.; Qu, Y.; Li, X.; Lu, C.T.; Xie, K.L.; Sun, X.L.; Fei, Z. Neuroprotective effect of osthole on MPP+-induced cytotoxicity in PC12 cells via inhibition of mitochondrial dysfunction and ROS production. Neurochem. Int. 2010, 57, $206-215$. [CrossRef] [PubMed]

22. Liu, J.H.; Zschocke, S.; Reininger, E.; Bauer, R. Inhibitory effects of Angelica pubescens f. biserrata on 5-lipoxygenase and cyclooxygenase. Planta Med. 1998, 64, 525-529. [CrossRef] [PubMed]

23. Zhang, Q.; Qin, L.; He, W.; Van Puyvelde, L.; Maes, D.; Adams, A.; Zheng, H.; De Kimpe, N. Coumarins from Cnidium monnieri and their antiosteoporotic activity. Planta Med. 2007, 73, 13-19. [CrossRef] [PubMed]

24. Matsuda, H.; Tomohiro, N.; Ido, Y.; Kubo, M. Anti-allergic effects of cnidii monnieri fructus (dried fruits of Cnidium monnieri) and its major component, osthol. Biol. Pharm. Bull. 2002, 25, 809-812. [CrossRef] [PubMed]

25. Jiang, G.; Liu, J.; Ren, B.; Tang, Y.; Owusu, L.; Li, M.; Zhang, J.; Liu, L.; Li, W. Anti-tumor effects of osthole on ovarian cancer cells in vitro. J. Ethnopharmacol. 2016, 193, 368-376. [CrossRef] [PubMed]

26. Wang, L.; Yang, L.; Lu, Y.; Chen, Y.; Liu, T.; Peng, Y.; Zhou, Y.; Cao, Y.; Bi, Z.; Liu, T.; et al. Osthole Induces Cell Cycle Arrest and Inhibits Migration and Invasion via PTEN/Akt Pathways in Osteosarcoma. Cell. Physiol. Biochem. 2016, 38, 2173-2182. [CrossRef] [PubMed]

27. Xu, X.M.; Zhang, M.L.; Zhang, Y.; Zhao, L. Osthole induces lung cancer cell apoptosis through inhibition of inhibitor of apoptosis family proteins. Oncol. Lett. 2016, 12, 3779-3784. [CrossRef]

28. Yang, Y.; Ren, F.; Tian, Z.; Song, W.; Cheng, B.; Feng, Z. Osthole Synergizes With HER2 Inhibitor, Trastuzumab in HER2Overexpressed N87 Gastric Cancer by Inducing Apoptosis and Inhibition of AKT-MAPK Pathway. Front. Pharmacol. 2018, 9, 1392. [CrossRef]

29. Sánchez, B.G.; Bort, A.; Mateos-Gómez, P.A.; Rodríguez-Henche, N.; Díaz-Laviada, I. Combination of the natural product capsaicin and docetaxel synergistically kills human prostate cancer cells through the metabolic regulator AMP-activated kinase. Cancer Cell Int. 2019, 19, 54. [CrossRef]

30. Singh, S.K.; Apata, T.; Gordetsky, J.B.; Singh, R. Docetaxel Combined with Thymoquinone Induces Apoptosis in Prostate Cancer Cells via Inhibition of the PI3K/AKT Signaling Pathway. Cancers (Basel) 2019, 11, 1390. [CrossRef]

31. Hu, X.J.; Liu, Y.; Zhou, X.F.; Zhu, Q.L.; Bei, Y.Y.; You, B.G.; Zhang, C.G.; Chen, W.L.; Wang, Z.L.; Zhu, A.J.; et al. Synthesis and characterization of low-toxicity N-caprinoyl-N-trimethyl chitosan as self-assembled micelles carriers for osthole. Int. J. Nanomed. 2013, 8, 3543-3558. [CrossRef] [PubMed]

32. Ten Tije, A.J.; Verweij, J.; Loos, W.J.; Sparreboom, A. Pharmacological effects of formulation vehicles: Implications for cancer chemotherapy. Clin. Pharmacokinet. 2003, 42, 665-685. [CrossRef] [PubMed]

33. Schwartzberg, L.S.; Navari, R.M. Safety of Polysorbate 80 in the Oncology Setting. Adv. Ther. 2018, 35, 754-767. [CrossRef] [PubMed]

34. Jo, M.J.; Jo, Y.H.; Lee, Y.J.; Park, C.W.; Kim, J.S.; Hong, J.T.; Chung, Y.B.; Lee, M.K.; Shin, D.H. Physicochemical, Pharmacokinetic, and Toxicity Evaluation of Methoxy Poly(ethylene glycol)-b-Poly(d,l-Lactide) Polymeric Micelles Encapsulating Alpinumisoflavone Extracted from Unripe Cudrania tricuspidata Fruit. Pharmaceutics 2019, 11, 366. [CrossRef] [PubMed]

35. Su, Y.; Wang, K.; Li, Y.; Song, W.; Xin, Y.; Zhao, W.; Tian, J.; Ren, L.; Lu, L. Sorafenib-loaded polymeric micelles as passive targeting therapeutic agents for hepatocellular carcinoma therapy. Nanomedicine (London, England) 2018, 13, 1009-1023. [CrossRef] [PubMed]

36. Zamani, M.; Shirinzadeh, A.; Aghajanzadeh, M.; Andalib, S.; Danafar, H. In vivo study of mPEG-PCL as a nanocarriers for anti-inflammatory drug delivery of simvastatin. Pharm. Dev. Technol. 2019, 24, 663-670. [CrossRef]

37. Wei, W.; Li, S.; Xu, H.; Zhou, F.; Wen, Y.; Song, Z.; Feng, S.; Feng, R. MPEG-PCL Copolymeric Micelles for Encapsulation of Azithromycin. AAPS PharmSciTech 2018, 19, 2041-2047. [CrossRef]

38. Kheiri Manjili, H.; Ghasemi, P.; Malvandi, H.; Mousavi, M.S.; Attari, E.; Danafar, H. Pharmacokinetics and in vivo delivery of curcumin by copolymeric mPEG-PCL micelles. Eur. J. Pharm. Biopharm. 2017, 116, 17-30. [CrossRef]

39. Cho, H.; Lai, T.C.; Kwon, G.S. Poly(ethylene glycol)-block-poly( $\varepsilon$-caprolactone) micelles for combination drug delivery: Evaluation of paclitaxel, cyclopamine and gossypol in intraperitoneal xenograft models of ovarian cancer. J. Control. Release 2013, 166, 1-9. [CrossRef]

40. Dou, J.; Zhang, H.; Liu, X.; Zhang, M.; Zhai, G. Preparation and evaluation in vitro and in vivo of docetaxel loaded mixed micelles for oral administration. Colloids Surf. B. Biointerfaces 2014, 114, 20-27. [CrossRef]

41. Dai, J.D.; Wang, X.Q.; Zhang, T.; Meng, M.; Zhang, X.; Lü, W.L.; Zhang, Q. [Preparation of cyclosporine A pH sensitive nanoparticles and oral pharmacokinetics in rats]. Yao Xue Xue Bao 2004, 39, 1023-1027. [PubMed]

42. Aw, M.S.; Kurian, M.; Losic, D. Polymeric micelles for multidrug delivery and combination therapy. Chemistry (Weinheim an der Bergstrasse, Germany) 2013, 19, 12586-12601. [CrossRef] [PubMed]

43. Chen, L.; Sha, X.; Jiang, X.; Chen, Y.; Ren, Q.; Fang, X. Pluronic P105/F127 mixed micelles for the delivery of docetaxel against Taxol-resistant non-small cell lung cancer: Optimization and in vitro, in vivo evaluation. International journal of nanomedicine 2013, 8, 73-84. [CrossRef] [PubMed]

44. Liao, J.; Song, Y.; Liu, C.; Li, D.; Zheng, H.; Lu, B. Dual-drug delivery based charge-conversional polymeric micelles for enhanced cellular uptake and combination therapy. Polymer Chemistry 2019, 10. [CrossRef] 
45. Rezazadeh, M.; Emami, J.; Hasanzadeh, F.; Sadeghi, H.; Minaiyan, M.; Mostafavi, A.; Rostami, M.; Lavasanifar, A. In vivo pharmacokinetics, biodistribution and anti-tumor effect of paclitaxel-loaded targeted chitosan-based polymeric micelle. Drug Deliv. 2016, 23, 1707-1717. [CrossRef]

46. Emami, J.; Rezazadeh, M.; Mashayekhi, M.; Rostami, M.; Jahanian-Najafabadi, A. A novel mixed polymeric micelle for codelivery of paclitaxel and retinoic acid and overcoming multidrug resistance: Synthesis, characterization, cytotoxicity, and pharmacokinetic evaluation. Drug Dev. Ind. Pharm. 2018, 44, 729-740. [CrossRef]

47. Kim, S.C.; Kim, D.W.; Shim, Y.H.; Bang, J.S.; Oh, H.S.; Wan Kim, S.; Seo, M.H. In vivo evaluation of polymeric micellar paclitaxel formulation: Toxicity and efficacy. J. Control. Release 2001, 72, 191-202. [CrossRef]

48. Liu, J.; Li, H.; Chen, D.; Jin, X.; Zhao, X.; Zhang, C.; Ping, Q. In vivo evaluation of novel chitosan graft polymeric micelles for delivery of paclitaxel. Drug Deliv. 2011, 18, 181-189. [CrossRef]

49. Zhang, C.; Qu, G.; Sun, Y.; Wu, X.; Yao, Z.; Guo, Q.; Ding, Q.; Yuan, S.; Shen, Z.; Ping, Q.; et al. Pharmacokinetics, biodistribution, efficacy and safety of N-octyl-O-sulfate chitosan micelles loaded with paclitaxel. Biomaterials 2008, 29, 1233-1241. [CrossRef]

50. Esmaeili, F.; Dinarvand, R.; Ghahremani, M.H.; Ostad, S.N.; Esmaily, H.; Atyabi, F. Cellular cytotoxicity and in-vivo biodistribution of docetaxel poly(lactide-co-glycolide) nanoparticles. Anticancer Drugs 2010, 21, 43-52. [CrossRef]

51. Twentyman, P.R.; Luscombe, M. A study of some variables in a tetrazolium dye (MTT) based assay for cell growth and chemosensitivity. Br. J. Cancer 1987, 56, 279-285. [CrossRef] [PubMed]

52. Chou, T.C. Drug combination studies and their synergy quantification using the Chou-Talalay method. Cancer Res. 2010, 70, 440-446. [CrossRef] [PubMed]

53. Zhang, H. Thin-Film Hydration Followed by Extrusion Method for Liposome Preparation. Methods Mol. Biol. 2017, 1522, 17-22. [CrossRef]

54. Xu, H.; Hou, Z.; Zhang, H.; Kong, H.; Li, X.; Wang, H.; Xie, W. An efficient Trojan delivery of tetrandrine by poly(Nvinylpyrrolidone)-block-poly( $\varepsilon$-caprolactone) (PVP-b-PCL) nanoparticles shows enhanced apoptotic induction of lung cancer cells and inhibition of its migration and invasion. International journal of nanomedicine 2014, 9, 231-242. [CrossRef] [PubMed]

55. Sun, C.; Liang, Y.; Hao, N.; Xu, L.; Cheng, F.; Su, T.; Cao, J.; Gao, W.; Pu, Y.; He, B. A ROS-responsive polymeric micelle with a $\pi$-conjugated thioketal moiety for enhanced drug loading and efficient drug delivery. Organic $\mathcal{E}$ biomolecular chemistry 2017, 15, 9176-9185. [CrossRef]

56. Zhang, W.; Li, C.; Jin, Y.; Liu, X.; Wang, Z.; Shaw, J.P.; Baguley, B.C.; Wu, Z.; Liu, J. Multiseed liposomal drug delivery system using micelle gradient as driving force to improve amphiphilic drug retention and its anti-tumor efficacy. Drug Deliv. 2018, 25, 611-622. [CrossRef]

57. Modi, S.; Anderson, B.D. Determination of Drug Release Kinetics from Nanoparticles: Overcoming Pitfalls of the Dynamic Dialysis Method. Mol. Pharm. 2013, 10, 3076-3089. [CrossRef]

58. Shin, D.H.; Park, S.H.; Jeong, S.W.; Park, C.W.; Han, K.; Chung, Y.B. Hepatic uptake of epirubicin by isolated rat hepatocytes and its biliary excretion after intravenous infusion in rats. Arch. Pharm. Res. 2014, 37, 1599-1606. [CrossRef] 